\title{
PENGENDALI SUHU PADA PROSES PASTEURISASI SUSU DENGAN MENGGUNAKAN METODE PID DAN METODE FUZZY SUGENO
}

\author{
Yosefine Triwidyastuti ${ }^{1}$, M. Nizar ${ }^{2}$, Harianto $^{3}$, Jusak Jusak ${ }^{4}$ \\ ${ }^{1,2,3}$ Program Studi Sistem Komputer, Institut Bisnis dan Informatika Stikom Surabaya \\ Email: ${ }^{1}$ yosefine@ stikom.edu, ${ }^{2}$ nizar@ @stikom.edu, ${ }^{3}$ hari@ stikom.edu, ${ }^{4}$ jusak@ @ stikom.edu
}

(Naskah masuk: 19 September 2018, diterima untuk diterbitkan: 27 Mei 2019)

\begin{abstract}
Abstrak
Proses pasteurisasi berfungsi untuk membunuh bakteri patogen yang dapat mengganggu kesehatan. Selain itu proses pasteurisasi juga bermanfaat untuk memperpanjang masa susu tidak rusak sehingga kualitas susu dapat dipertahankan sampai jangka waktu tertentu. Pada penelitian pengabdian masyarakat ini proses pasteurisasi susu dengan model low temperature long time (LTLT) dibangun dengan menggunakan pengendali PID dan pengendali Fuzzy. Model LTLT dipilih karena adanya kebutuhan masyarakat untuk dapat mencampur susu dengan berbagai perasa selama proses pasteurisasi berlangsung. Tujuan akhir dari penambahan perasa pada susu adalah untuk meningkatkan daya jual dari susu pasteurisasi. Berdasarkan hasil pengujian diperoleh kesimpulan bahwa sistem pengendali PID dengan nilai $K_{p}=31,8 ; K_{I}=117,8 ; K_{D}=4,3$ memberikan respon lebih cepat daripada sistem pengendali Fuzzy berdasarkan pengukuran indikator waktu tunda, waktu naik, waktu puncak dan waktu penetapan. Sebaliknya sistem pengendali Fuzzy menghasilkan nilai mean squared error (MSE) lebih kecil daripada sistem pengendali PID yang menunjukkan bahwa sistem pengendali Fuzzy memiliki fluktuasi kesalahan lebih kecil daripada sistem pengendali PID dalam proses pasteurisasi susu. Akan tetapi, MSE kedua pengendali berada di bawah nilai 1\%, hal ini menunjukkan bahwa kedua pengendali dapat mempertahankan suhu susu sesuai dengan rentang suhu standar untuk pasteurisasi susu. Hasil pengujian laboratorium terhadap susu hasil proses pasteurisasi menunjukkan bahwa jumlah cemaran mikroba telah turun pada jumlah sesuai dengan standar SNI pada saat yang sama kualitas susu hasil proses pasteurisasi tetap terjaga.
\end{abstract}

Kata kunci: pasteurisasi, low temperature long time, proportional-integral-derivative, metode fuzzy Sugeno

\section{TEMPERATURE CONTROL FOR MILK PASTEURIZATION UTILIZING THE PROPORTIONAL-INTEGRAL-DERIVATIVE (PID) AND FUZZY SUGENO METHOD}

\begin{abstract}
Milk pasteurization process has benefit for reducing pathogenic bacteria that may harm people's health. At the same time, this process can be used to maintain the milk quality for long period of time. In this research, a milk pasteurization process that based on the low temperature long time (LTLT) was built utilizing the ProportionalIntegral-Derivative and the Fuzzy system methods. The LTLT method was chosen in this project due to the need to blend the pasteurized milk with several type of food flavoring to increase the selling power of the pasteurized milk. Therefore, it needs longer pasteurization time. Based on the 30 trials of examination, it showed that the PID controller with values of $K_{p}=31,8 ; K_{I}=117,8 ; K_{D}=4,3$ was able to provide a faster system response time compared to the Fuzzy controller. The measurement was done utilizing several indicators including delay time, rise time, peak time as well as settling time. In contrast, the Fuzzy controller produced a smaller mean squared error (MSE) compared to the PID controller showing that the Fuzzy controller produced smaller error fluctuation in the milk pasteurization process. Nevertheless, the results showed that both controllers exhibited MSE lower than 1\%, it indicates that both controllers could maintain milk temperature at the range of the standardized milk pasteurization process. Moreover, laboratory examination showed that using both pasteurization methods the number of coliform bacteria have been decreased to meet with the SNI standard and at the same time it was able to maintain the quality of the milk.
\end{abstract}

Keywords: pasteurization, low temperature long time, proportional-integral-derivative, fuzzy Sugeno method 


\section{PENDAHULUAN}

Susu segar yang berasal dari sapi sehat merupakan bahan makanan yang mengandung sejumlah nutrisi bergizi tinggi untuk manusia. Komposisi nutrisi pada susu sapi segar meliputi air, lemak, protein, laktosa, dan mineral (Resnawati, 2008). Namun demikian, sekalipun susu mengandung berbagai macam zat gizi, diketahui bahwa susu juga merupakan tempat berkembang biak yang baik bagi berbagai macam mikroorganisme. Hal ini terutama disebabkan karena susu segar secara alami memiliki pH sebesar 6,8 (Suwito, 2010).

Mikroorganisme yang dibiarkan berkembang dalam susu pertama-tama akan menyebabkan susu menjadi rusak. Namun kondisi yang paling merugikan akan terjadi apabila susu tersebut dikonsumsi oleh konsumen akhir. Sehingga susu yang rusak akan menyebabkan gangguan kesehatan mulai sakit perut biasa, dehidrasi sampai kondisi yang lebih parah mengakibatkan kematian.

Salah satu cara yang dapat digunakan untuk mempertahankan kondisi susu agar tetap sehat dengan kondisi $\mathrm{pH}$ dan jumlah mikroorganisme terjaga adalah dengan menggunakan proses pasteurisasi. Proses pasteurisasi dilakukan dengan cara pemanasan dengan tujuan untuk membunuh bakteri patogen yang dapat membahayakan kesehatan (Saleh, 2004). Sesuai dengan Standar Nasional Indonesia (SNI 01-3951-1995), terdapat dua macam cara dalam melakukan proses pemanasan pada susu, yaitu:

(i) Low Temperature Long Time (LTLT) dengan pemanasan susu pada suhu $63^{\circ} \mathrm{C}-$ $66^{\circ} \mathrm{C}$ selama rentang waktu 30 menit.

(ii) High Temperature Short Time (HTST) dengan pemanasan susu pada suhu $72{ }^{\circ} \mathrm{C}$ selama rentang waktu 15 detik.

Kedua proses di atas selanjutnya diikuti segera dengan pendinginan sampai suhu $10{ }^{\circ} \mathrm{C}$ dan disimpan pada suhu maksimum $4,4{ }^{\circ} \mathrm{C}$. Apabila pemanasan pada susu dilakukan melebihi standar yang telah ada, maka akan berpotensi terhadap kehilangan lysin dan vitamin pada susu. Sebaliknya apabila pemanasan pada susu dilakukan di bawah standar, maka proses pasteurisasi belum secara efektif mengurangi bakteri patogen dalam susu.

Selain membunuh bakteri patogen yang dapat mengganggu kesehatan, proses pasteurisasi juga bermanfaat untuk memperpanjang masa susu tidak rusak sehingga kualitas susu dapat dipertahankan sampai jangka waktu tertentu. Dengan demikian proses pasteurisasi susu bermanfaat secara ekonomis bagi peternak sapi perah, antara lain: harga ekonomis susu pasteurisasi lebih tinggi daripada susu tanpa pasteurisasi, kedua, daya tahan susu yang lama memungkinkan susu disimpan (tidak perlu dibuang apabila susu tidak dikonsumsi).

Teknologi pasteurisasi telah ada di Indonesia sejak beberapa dekade yang lalu. Namun dengan semakin bekembangnya teknologi kontrol dan otomasi industri yang memanfaatkan bidang ilmu kecerdasan buatan, kemampuan perangkat pengendali proses pasteurisasi untuk mempertahankan suhu stabil pada titik (set point) yang diharapkan dalam rentang waktu tertentu juga semakin berkembang. Berikut ini adalah beberapa contoh hasil penelitian teknologi pengendali proses pasteurisasi yang ada dan telah diujicobakan.

Teknologi proses pasteurisasi dengan menggunakan pengendali Model Predictive Control (MPC) diharapkan dapat menghasilkan keluaran berupa pengendalian suhu susu agar stabil pada target suhu yang diharapkan sebesar $72{ }^{\circ} \mathrm{C}$ (Anang, Hadisupadmo, \& Leksono, 2016; Alamirew, Balaji, \& Gabbeye, 2017). Dalam uji coba proses pasteurisasi, model pengendali MPC yang dibangun dengan menggunakan perangkat lunak MATLAB dapat meminimalkan terjadinya lonjakan (overshoot) dengan waktu penetapan (settling time) 712 detik. Pada makalah yang lain, pengendali MPC digunakan dengan memanfaatkan model Linear Parameter Varying (LPV) dengan berbagai strategi untuk mengatur suhu pada proses pasteurisasi dalam skala laboratorium (Pour, Puic, \& Martinez, 2017). Dalam makalah disebutkan bahwa terdapat 3 strategi yang telah diujicobakan meliputi: pure- $L P V$, quasi- $L P V$ dan Robust $M P C$. Berdasarkan hasil pengujian diperoleh fakta bahwa strategi pure- $L P V$ menghasilkan waktu respon sistem (system response) tercepat dan kesalahan posisi stabil (steady-state error) terkecil dibandingkan dengan kedua strategi yang lain. Secara keseluruhan ketiga strategi tersebut dapat mencapai suhu yang diharapkan dalam proses pasteurisasi HTST, yaitu pada suhu $72{ }^{\circ} \mathrm{C}$.

Penelitian lain dalam proses pasteurisasi susu memfokuskan pada tercapainya proses pemanasan cepat dan merata dengan menggunakan teknologi Radio Frequency Electric Field (RFEF). Dengan pemanasan cepat diharapkan agar bakteri patogen dapat dimatikan tetapi pada saat yang sama zat-zat gizi lain pada makanan tidak rusak. Hasil pengujian terhadap proses pasteurisasi susu dilaporkan bahwa suhu dari susu dapat meningkat mencapai titik $72,3{ }^{\circ} \mathrm{C}$ dalam waktu 2 menit dan mampu mengurangi populasi bakteri sampai $109.260 \mathrm{cfu} / \mathrm{ml}$ (Srisuma, Santaluna, Thosdeekoraphat, \& Thongsopa, 2017).

Penelitian selanjutnya menguji penggunaan metode Proportional-Integral-Derivative (PID), Fuzzy Inference System (FIS) dan Artificial Neural Network Fuzzy Inference System (ANFIS) dalam proses pasteurisasi susu menggunakan metode HTST (Maulana, Hadisupadmo, \& Leksono, 2016). Berdasarkan pengujian dapat disimpulkan bahwa proses pasteurisasi dengan menggunakan metode ANFIS menghasilkan nilai lonjakan terkecil dibanding metode pengendali yang lain. Lonjakan hanya mencapai $0,27 \%$. Sedangkan nilai mean squared error (MSE) yang dapat dicapai oleh metode ANFIS setelah waktu stabil terpenuhi adalah 0,114. Akan tetapi metode ANFIS memiliki kekurangan 
yaitu sangat reaktif terhadap gangguan yang berupa impuls pada sistem.

Sekalipun sebagian besar standar industri dan beberapa penelitian di atas menggunakan model pasteurisasi HTST, namun dalam beberapa survei yang telah dilakukan sebelumnya didapati bahwa masyarakat peternak sapi dan Industri Pengolah Susu (IPS) masih memerlukan model pemanasan lambat karena adanya kebutuhan untuk menambahkan perasa pada susu. Hal ini tidak mungkin dilakukan dengan menggunakan pasteurisasi pemanasan cepat karena dibutuhkan waktu tertentu untuk proses pelarutan perasa pada susu. Dengan adanya penambahan perasa pada susu diharapkan dapat meningkatkan daya jual dari susu pasteurisasi tersebut. Karena itu model pasteurisasi LTLT akan sangat bermanfaat dalam konteks ini.

Proses pasteurisasi susu secara LTLT yang telah menjadi praktik umum pada saat ini dilakukan secara manual, yaitu dengan cara mengaduk susu yang telah diletakkan di atas tungku api selama kurang lebih 30 menit. Pasteurisasi manual semacam ini memiliki beberapa kekurangan, misalnya pengukuran terhadap suhu dari susu dilakukan dengan perkiraan atau kalau menggunakan termometer pengukuran harus dilakukan secara berulang-ulang. Pengukuran suhu susu secara manual tersebut harus dibarengi oleh proses mematikan dan menyalakan tungku api secara terus menerus untuk menjaga agar suhu susu tetap berada di dalam rentang standar pasteurisasi LTLT. Sebagai konsekuensi dari proses pemanasan yang tidak akurat, tingkat berkurangnya jumlah mikroorganisme dalam susu dan tingkat penurunan kualitas susu setelah proses pasteurisasi manual tidak dapat dipastikan.

Pada penelitian pengabdian masyarakat ini proses pasteurisasi susu dibangun dengan menggunakan pengendali PID dan pengendali Fuzzy dengan menggunakan model pasteurisasi LTLT. Kedua model tersebut dipilih untuk mengendalikan proses pasteurisasi LTLT karena keduanya memiliki kompleksitas rendah, sehingga keduanya dapat diterapkan dengan baik pada sistem pengendali dengan dengan ukuran memori kecil (Ichsan, Setiawan, \& Hamidi, 2016; Setyawan, Setiawan, \& Kurniawan, 2015).

Kontribusi utama hasil penelitian ini adalah 2 (dua) hal, yaitu: (1) melakukan otomatisasi proses pasteurisasi susu dengan metode LTLT untuk menjaga suhu susu pada titik $64^{\circ} \mathrm{C}$ selama waktu proses 30 menit, (2) turut serta dalam meningkatkan kontribusi ekonomi (tujuan jangka panjang) dan pemahaman akan proses pasteurisasi bagi peternak dan pengusaha UMKM.

Secara keseluruhan, laporan penelitian pengabdian masyarakat ini tersusun atas urutan sebagai berikut. Bagian 1 menjelaskan latar belakang, tujuan serta kontribusi utama dari penelitian ini. Bagian 2 mengulas metode penelitian yang digunakan. Bagian 3 menunjukkan hasil-hasil penelitian beserta pembahasannya. Laporan penelitian ditutup dengan kesimpulan pada Bagian 4.

\section{METODE PENELITIAN}

Dalam penelitian pengabdian masyarakat ini akan dibangun purwarupa perangkat pasteurisasi susu dengan menggunakan pengendali PID dan pengendali Fuzzy. Model dari sistem pengendali pasteurisasi susu ditunjukkan dalam Gambar 1.

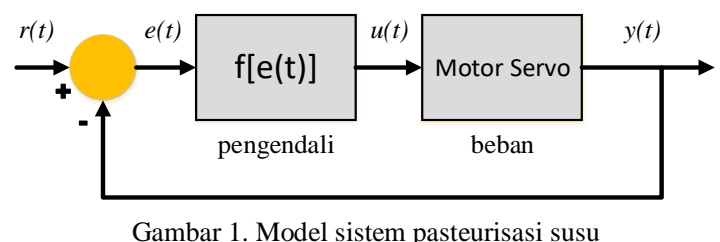

Gambar 1 menunjukkan model sistem otomatis pasteurisasi susu dengan tujuan akhir untuk mengendalikan nilai suhu pada sisi keluaran, $y(t)$, sedemikian rupa sehingga nilai keluaran tersebut berada pada suhu pasteurisasi LTLT, yaitu pada suhu $y(t) \approx 64^{\circ} \mathrm{C}$. Motor servo merupakan beban (plant) yang berfungsi sebagai pengatur besar kecilnya api pada tungku pemanas untuk menaikkan atau menurunkan suhu dari susu. Pada Gambar 1, variabel $r(t)$ merepresentasikan suhu masukan atau set point bagi sistem pasteurisasi susu, sedangkan nilai $u(t)$, didefinisikan oleh persamaan (1),

$u(t)=f[e(t)]$

Fungsi $f[e(t)]$ adalah pengendali PID atau Fuzzy yang melakukan fungsi penyesuaian nilai $u(t)$ berdasarkan nilai kesalahan yang diterima. Nilai kesalahan, $e(t)$, didefinisikan oleh persamaan (2),

$e(t)=r(t)-y(t)$

Blok diagram implementasi yang menunjukkan secara detail komponen-komponen penyusun sistem pasteurisasi susu dalam penelitian ini ditunjukkan dalam Gambar 2.

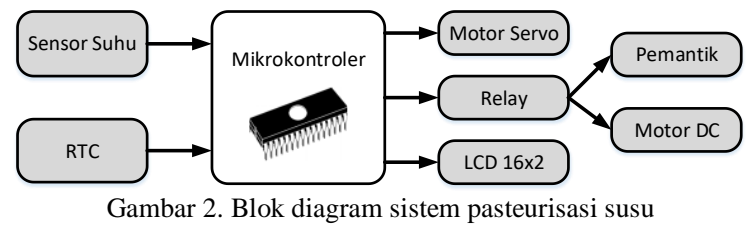

Masukan dari sistem pasteurisasi susu terdiri atas: sensor suhu yang berfungsi sebagai pengukur suhu susu (dibenamkan ke dalam susu) dan sebuah Real Time Clock (RTC) sebagai pewaktu. Pengendali utama dalam proses pasteurisasi susu adalah sebuah mikrokontroler yang berfungsi sebagai pengolah data yang berasal dari masukan berupa suhu aktual yang terukur oleh sensor suhu. Selanjutnya pengolahan data untuk pengendalian suhu proses pasteurisasi 
digunakan PID dan sistem Fuzzy. Keluaran dari sistem terdiri atas: sebuah motor servo yang berfungsi sebagai aktuator untuk menentukan besar kecilnya api pada tungku pemanas, sebuah pemantik elektrik berfungsi sebagai pemicu api pada tungku pemanas, sebuah motor DC berfungsi sebagai penggerak pengaduk susu sehingga suhu pada susu mengalami pemerataan pada saat proses pemanasan berlangsung dan sebuah LCD (Liquid Crystal Display) untuk menampilkan suhu dan waktu proses. Bentuk fisik dari purwarupa pasteurisasi susu yang telah dibangun pada penelitian ini ditunjukkan dalam Gambar 3.

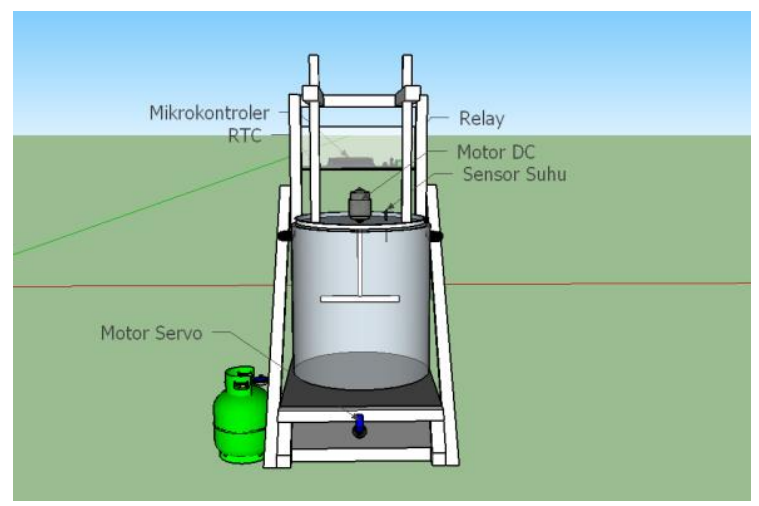

Gambar 3. Model fisik sistem pasteurisasi susu

\section{HASIL DAN PEMBAHASAN}

Sistem pengendali utama dalam proses pasteurisasi susu adalah perangkat mikrokontroler Atmega16 yang berisi program PID dan sistem Fuzzy. Atmega16 merupakan seri mikrokontroler CMOS 8bit yang dibuat oleh Atmel. Mikrokontroler ini merupakan pemroses berbasis arsitektur Reduced Instruction Set Computer (RISC). Karena itu hampir semua instruksi untuk mikrokontroler ini dapat dieksekusi dalam satu siklus clock. Atmega16 dilengkapi dengan memori flash 16KB, memori EEPROM sebesar $512 \mathrm{~B}$, SRAM sebanyak 1KB, perangkat I/O sebanyak 32 buah, register generalpurpose 32 buah, ADC 10 bit, timer/counter, internal dan external interrupt, serial UART, power mode saving, ADC dan PWM internal. ATMega16 memiliki throughput mendekati 1 MIPS per $\mathrm{MHz}$ dan beroperasi pada tegangan 2,75 - 5,5 Volt (Atmel, 2002). Rangkaian perangkat keras sistem pengendali pasteurisasi susu ditunjukkan dalam Gambar 4.

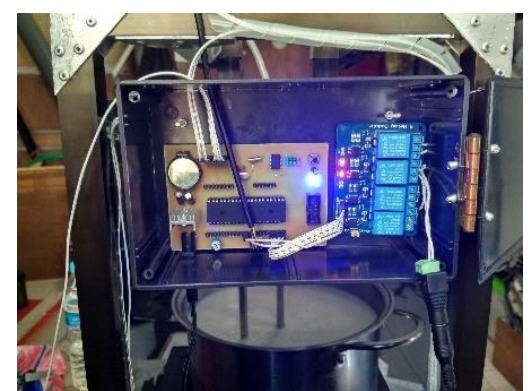

Gambar 4. Rangkaian perangkat keras sistem pengendali pasteurisasi susu
Sebagai masukan bagi mikrokontroler, digunakan sebuah sensor suhu DS18B20. Sensor ini merupakan sebuah sensor digital 1 wire (Maxim, 2015). Salah satu nilai tambah dari sensor ini adalah bahwa setiap sensor memiliki kode serial yang memungkinkan untuk penggunaan DS18B20 lebih dari satu dalam komunikasi 1 wire. DS18B20 merupakan sensor suhu digital yang dikeluarkan oleh Maxim Integrated Products, Inc. Sensor ini dilengkapi dengan 3 pin yang terdiri atas VDD sebagai sumber tenaga, ground (GND) dan data in/out (DQ).

Keluaran dari sistem adalah putaran motor servo yang terhubung pada sistem pemanas tungku untuk mengatur dan mengendalikan besar kecilnya api. Besar kecilnya api selanjutnya akan berpengaruh langsung terhadap naik turunnya suhu dari susu.

Dalam penelitian ini, uji coba sistem pengendali pasteurisasi susu dilakukan sebanyak 30 kali dalam rentang waktu 30 menit untuk masing-masing proses pasteurisasi susu. Perhitungan waktu 30 menit dihitung setelah suhu mencapai titik $64^{\circ} \mathrm{C}$, yaitu setelah waktu naik (rise time) tercapai.

\subsection{Pengendali PID}

Pengendali PID merupakan pengendali konvensional yang telah banyak digunakan pada sistem otomatisasi industri. Sesuai dengan namanya, pengendali PID merupakan penjumlahan keluaran dari 3 buah pengendali, yaitu pengendali proporsional (P), pengendali integral (I) dan pengendali derivatif (D). Karakteristik keluaran dari pengendali PID sangat ditentukan oleh 3 buah parameter, yaitu $K_{p}, K_{I}$, dan $K_{D}$. Pada penelitian ini nilai $K_{p}, K_{I}$, dan $K_{D}$ ditentukan dengan menggunakan metode ZieglerNichols tipe 2 (Ogata, 2010).

Proses penentuan parameter PID dilakukan dengan mengukur respon dari sistem yang dikendalikan oleh sebuah slider gain untuk menghasilkan respon berosilasi. Proses penentuan nilai $K_{p}, K_{I}$, dan $K_{D}$ dilakukan sesuai dengan urutan berikut:

i. Mula-mula nilai $K_{I}$ dan $K_{D}$ diatur pada posisi 0 atau $O F F$, sedangkan nilai $K_{p}$ dinaikkan secara pelahan-lahan mulai dari nilai 0 hingga mencapai titik tertentu ketika kurva respon berosilasi terus menerus. Nilai $K_{p}$ pada saat kurva respon berosilasi terus menerus disebut sebagai $K_{U}$. Gambar 5 menunjukkan respon sistem pada saat $K_{U}=53$.

ii. Pada kurva respon sistem yang berosilasi terusmenerus dilakukan perhitungan nilai $P_{U}$, yaitu periode antara dua puncak osilasi seperti ditunjukkan pada Gambar 5. Nilai $P_{U}$ ditunjukkan oleh persamaan (3).

$$
\begin{aligned}
P_{U} & =x_{1}-x_{0} \\
& =12,36-11,28=1,08
\end{aligned}
$$




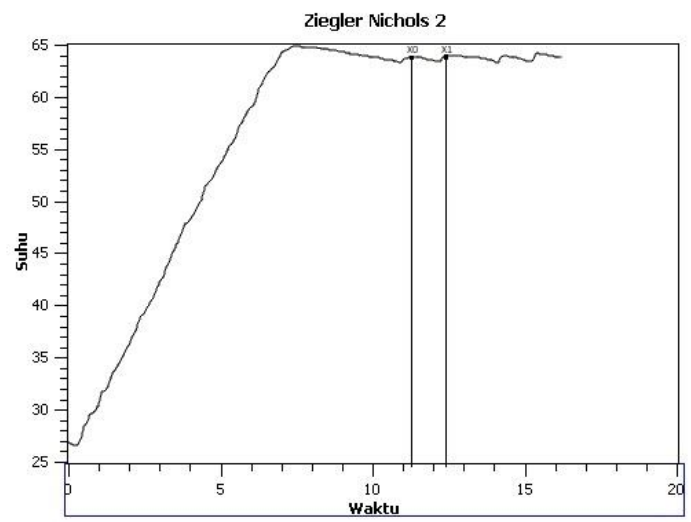

Gambar 5. Kurva respon dari sistem untuk nilai $K_{U}=53$.

iii. Setelah nilai $K_{U}$ dan $P_{U}$ diperoleh, maka langkah selanjutnya adalah mensubstitusikan nilai-nilai tersebut pada persamaan yang telah didefinisikan oleh Ziegler-Nichols, seperti ditunjukkan pada persamaan (4) sampai persamaan (8).

$$
\begin{aligned}
& K_{p}=0,6 K_{U}=0,6 \times 53=\mathbf{3 1 , 8} \\
& T_{I}=0,5 P_{U}=0,5 \times 1,08=0,54 \\
& T_{D}=0,125 P_{U}=0,125 \times 1,08=0,135 \\
& K_{I}=2 \times \frac{K_{p}}{T_{I}}=2 \times \frac{31,8}{0,54}=\mathbf{1 1 7 , 8} \\
& K_{D}=K_{p} \times T_{D}=31,8 \times 0,135=\mathbf{4 , 3} .
\end{aligned}
$$

Berdasarkan hasil pengujian, nilai $K_{p}=$ 31,8; $K_{I}=117,8 ; K_{D}=4,3 \quad$ digunakan dalam penelitian ini untuk mendapatkan titik stabil pada nilai suhu pasteurisasi $64^{\circ} \mathrm{C}$.

Diagram respon waktu untuk proses pasteurisasi susu dengan pengendali PID yang merupakan ratarata dari 30 percobaan ditunjukkan dalam Gambar 6. Sementara itu, rata-rata indikator respon waktu dari seluruh percobaan untuk masing-masing sistem ditunjukkan dalam Tabel 1.

Pengukuran kualitas sistem pengendali pasteurisasi susu baik menggunakan PID maupun Fuzzy dilakukan dengan menggunakan 6 (enam) buah indikator seperti ditunjukkan dalam Tabel 1. Waktu tunda (delay time) dihitung pada saat sistem mencapai separuh $(50 \%)$ dari suhu susu yang diinginkan. Waktu naik (rise time) dihitung pada saat sistem mencapai suhu susu yang diinginkan pertama kali. Waktu puncak (peak time) adalah waktu pada saat sistem mencapai suhu tertinggi pertama kali. Lewatan maksimum (maximum overshoot) merupakan persentase kenaikan maksimum yang dicapai oleh sistem terhadap suhu susu yang diinginkan. Sedangkan mean squared error (MSE) adalah indikator pengukur kesalahan suhu selama rentang waktu 30 menit.

\subsection{Pengendali Fuzzy}

Pengendali Fuzzy dalam proses pasteurisasi susu dalam penelitian ini menggunakan sistem Fuzzy dengan model Sugeno. Masukan dari sistem Fuzzy terdiri atas 2 masukan, yaitu (i) suhu aktual yang terukur pada sensor suhu disimbolkan sebagai $x$ dan (ii) perubahan suhu aktual sesaat disimbolkan sebagai $y$. Himpunan Fuzzy dari suhu aktual dan perubahan suhu ditunjukkan dalam Gambar 7 .

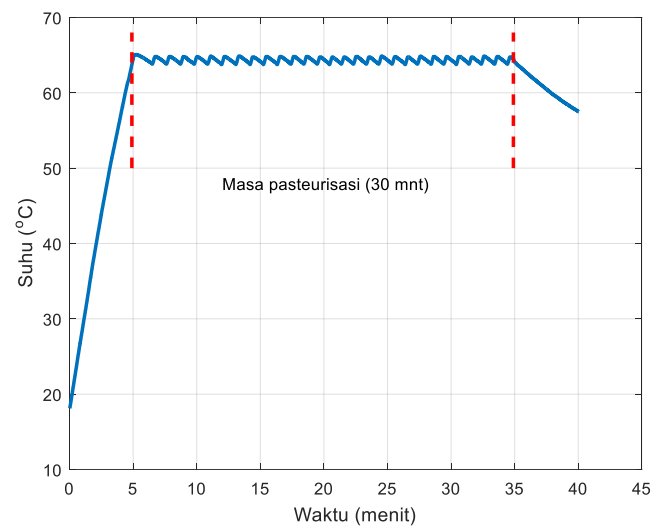

Gambar 6. Diagram respon waktu untuk proses pasteurisasi susu dengan pengendali PID

Tabel 1. Indikator respon waktu proses pasteurisasi susu

\begin{tabular}{ccc}
\hline Indikator & PID & Fuzzy \\
\hline Waktu tunda (delay time) & $2,20 \mathrm{mnt}$ & $3,68 \mathrm{mnt}$ \\
Waktu naik (rise time) & $4,93 \mathrm{mnt}$ & $8,08 \mathrm{mnt}$ \\
Waktu puncak (peak time) & $5,12 \mathrm{mnt}$ & $8,23 \mathrm{mnt}$ \\
Lewatan maksimum (max. & $1,66 \%$ & $0,48 \%$ \\
Overshoot) & $5,12 \mathrm{mnt}$ & $8,23 \mathrm{mnt}$ \\
Waktu penetapan (settling time) & 0,24 & 0,06 \\
Mean squared error (MSE) & &
\end{tabular}
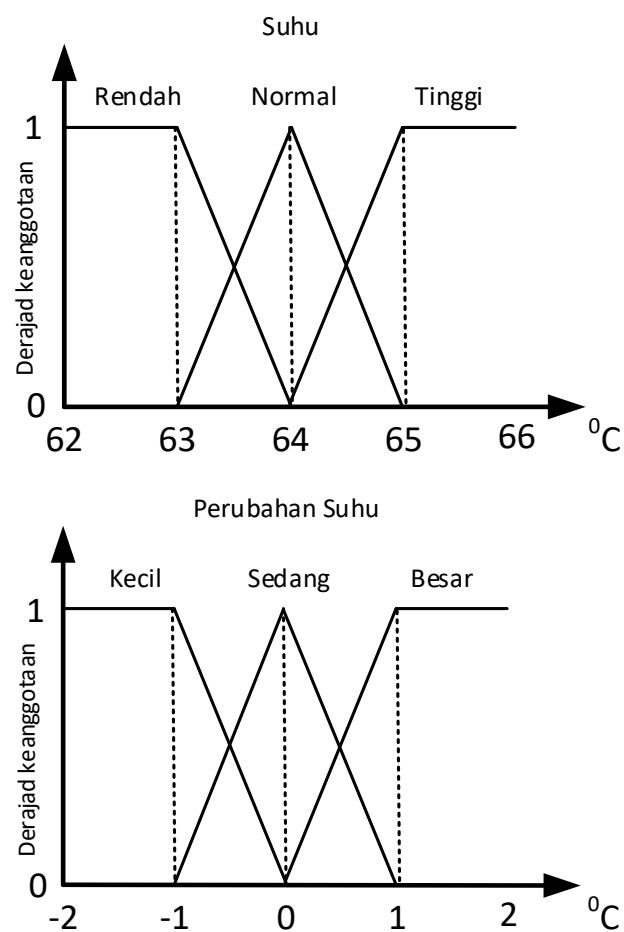

Gambar 7. Himpunan Fuzzy suhu dan perubahan suhu

Seperti terlihat dalam Gambar 7, himpunan Fuzzy suhu terdiri atas 3 (tiga) buah sub-himpunan antara lain rendah, normal, tinggi. Sedangkan himpunan Fuzzy perubahan suhu terdiri atas 3 (tiga) 
buah sub-himpunan yang meliputi kecil, sedang, besar. Perubahan suhu merupakan selisih antara hasil pengukuran suhu saat ini dengan nilai pengukuran suhu sebelumnya. Terlihat dalam Gambar 7 bahwa nilai perubahan suhu diharapkan terjadi pada nilai $\pm 1^{\circ} \mathrm{C}$ agar fluktuasi suhu pada proses pasteurisasi tidak melebihi standar pasteurisasi susu.

Keluaran dari pengendali sistem Fuzzy adalah putaran motor servo yang dikendalikan dengan menggunakan aturan Fuzzy Sugeno seperti ditunjukkan dalam Tabel 2.

Tabel 2. Aturan Fuzzy Sugeno untuk pengendali pasteurisasi susu IF Suhu Rendah and Perubahan Suhu Kecil then Servo Besar IF Suhu Rendah and Perubahan Suhu Sedang then Servo Besar

IF Suhu Rendah and Perubahan Suhu Besarthen Servo Kecil IF Suhu Normal and Perubahan Suhu Kecil then Servo Mati IF Suhu Normal and Perubahan Suhu Sedang then Servo Mati

IF Suhu Normal and Perubahan Suhu Besar then Servo Mati IF Suhu Tinggi and Perubahan Suhu Kecil then Servo Mati IF Suhu Tinggi and Perubahan Suhu Sedang then Servo Mati IF Suhu Tinggi and Perubahan Suhu Besar then Servo Mati

\section{Keterangan:}

Besar (sudut putaran servo $0^{\circ}$ ),

Kecil (sudut putaran servo $55^{\circ}$ ),

Mati (sudut putaran servo $90^{\circ}$ ).

Berdasarkan hasil pengujian, diagram respon waktu untuk proses pasteurisasi susu dengan pengendali Fuzzy yang merupakan rata-rata dari 30 percobaan ditunjukkan dalam Gambar 8. Sedangkan rata-rata indikator respon waktu dari 30 kali percobaan ditunjukkan dalam Tabel 1.

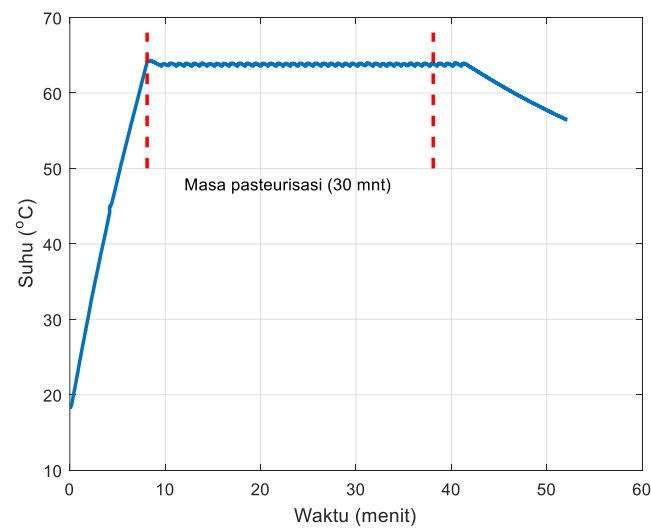

Gambar 8. Diagram respon waktu untuk proses pasteurisasi susu dengan pengendali Fuzzy

Gambar 8 menunjukkan perubahan suhu susu mulai dari suhu sekitar $18^{\circ} \mathrm{C}$ menuju ke suhu tujuan untuk pasteurisasi yaitu $64^{\circ} \mathrm{C}$. Selanjutnya suhu dari susu dipertahankan pada suhu $64^{\circ} \mathrm{C}$ selama waktu 30 menit. Setelah waktu 30 menit tercapai maka sistem akan secara otomatis mematikan tungku pemanas. Terlihat dalam Gambar, setelah waktu 30 menit masa pasteurisasi tercapai, suhu dari susu akan turun secara perlahan-lahan.

\subsection{Pembahasan}

Diagram respon waktu pengendali PID pada Gambar 6 dan juga indikator respon waktu pada Tabel 1 menunjukkan bahwa sistem pengendali pasteurisasi dengan metode PID memberikan waktu tunda, waktu naik dan puncak lebih kecil daripada sistem pengendali Fuzzy, yaitu waktu tunda pada nilai 2,20 menit, waktu naik pada 4,93 menit dan waktu puncak pada menit ke-5,12. Hal ini mengindikasikan bahwa sistem pengendali PID dengan penetapan nilai $K_{p}, K_{I}$, dan $K_{D}$ seperti ditunjukkan dalam sub-bab 3.1 memiliki respon lebih cepat daripada sistem pengendali Fuzzy.

Sebaliknya, pengamatan terhadap parameter uji lewatan maksimum dan mean squared error (MSE) pada sistem pengendali Fuzzy dalam Tabel 1, menunjukkan bahwa sistem pengendali Fuzzy memiliki nilai lewatan maksimum dan MSE lebih kecil daripada sistem pengendali PID. Hal ini berarti bahwa pengendali Fuzzy memberikan akurasi pencapaian suhu lebih baik daripada sistem pengendali PID.

Evolusi kesalahan kuadrat (squared error) kedua sistem pengendali ditunjukkan dalam Gambar 9. Kesalahan kuadrat merupakan selisih antara nilai suhu aktual pada waktu tertentu dengan nilai suhu tujuan $64^{\circ} \mathrm{C}$. Seperti terlihat dalam Gambar 9, perhitungan kesalahan kuadrat dimulai pada saat suhu susu telah mencapai $64^{\circ} \mathrm{C}$. Pada sistem pengendali PID, nilai kesalahan kuadrat muncul pada menit ke4,93, yaitu waktu naik dari sistem pengendali PID dan berakhir pada menit ke 34,93. Hal ini dengan jelas menunjukkan bahwa proses pasteurisasi susu berlangsung selama 30 menit sebagaimana dibutuhkan pada sistem pasteurisasi LTLT.
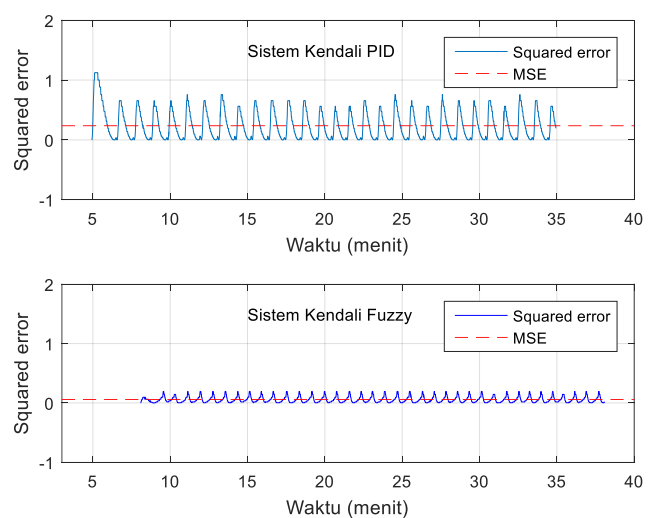

Gambar 9. Squared Error untuk sistem pengendali PID dan Fuzzy.

Pada sistem pengendali Fuzzy, nilai kesalahan kuadrat mulai muncul pada saat waktu naik mencapai waktu 8,09 menit dan berakhir pada menit ke 38,09. Gambar 9 bersama-sama dengan Tabel 1 menunjukkan dengan jelas bahwa rata-rata kesalahan kuadrat dari sistem pengendali Fuzzy lebih kecil daripada sistem pengendali PID. Hal ini berarti 
bahwa sistem pengendali Fuzzy memiliki tingkat kesalahan pencapaian target suhu lebih kecil daripada pengendali PID. Sekalipun demikian, Tabel 1 menunjukkan bahwa MSE kedua model pengendali di bawah 1\% untuk pengukuran waktu pemanasan selama 30 menit. Karena itu dapat disimpulkan bahwa akurasi suhu yang dicapai oleh pengendali PID dan pengendali Fuzzy masih memenuhi standar suhu untuk pasteurisasi susu, yaitu pada rentang suhu $63{ }^{\circ} \mathrm{C}-66^{\circ} \mathrm{C}$.

Selanjutnya, untuk menguji keberhasilan proses pasteurisasi susu dilakukan pengujian laboratorium terhadap susu. Hasil pengujian laboratorium terhadap susu murni yang belum dipasteurisasi dibandingkan dengan susu yang telah dipasteurisasi ditunjukkan dalam Tabel 3. Jenis atau parameter pengujian kedua jenis susu telah disesuaikan dengan Standar Nasional Indonesia (SNI 01-3951-1995) tentang susu pasteurisasi.

Berdasarkan hasil pengujian laboratorium nampak bahwa proses pasteurisasi susu dengan menggunakan metode otomatisasi yang telah dibangun pada penelitian ini berhasil menurunkan jumlah cemaran mikroba, yaitu bakteri coliform. Pada susu murni sebelum proses pasteurisasi jumlah coliform adalah $28 \mathrm{APM} / \mathrm{g}$, sedangkan jumlah coliform pada susu hasil proses pasteurisasi LTLT adalah < $3 \mathrm{APM} /$ g. Sedangkan Angka Lempeng Total (ALT) menurun dari 18,0 × 10 2 koloni/g menjadi $8,4 \times 10^{2} \mathrm{koloni} / \mathrm{g}$. Secara keseluruhan jumlah kandungan mikroba setelah proses pasteurisasi telah memenuhi SNI 01-3951-1995 tentang susu pasteurisasi.

\begin{tabular}{|c|c|c|}
\hline Jenis Pengujian & $\begin{array}{c}\text { Belum } \\
\text { Pasteurisasi }\end{array}$ & $\begin{array}{c}\text { Setelah } \\
\text { Pasteurisasi }\end{array}$ \\
\hline \multicolumn{3}{|l|}{ Keadaan } \\
\hline a. Bau & Normal & Normal \\
\hline b. Rasa & Masam & Gurih \\
\hline c. Warna & Putih & Putih \\
\hline d. Tekstur & Agak kental & Encer \\
\hline e. Bentuk & Cairan & Cairan \\
\hline Berat Jenis $(\mathrm{g} / \mathrm{ml})$ & 1,03 & 1,04 \\
\hline Lemak $(\%)$ & 11,42 & 10,24 \\
\hline Protein $(\mathrm{Nx} 6.38)(\%)$ & 2,99 & 3,30 \\
\hline \multicolumn{3}{|l|}{ Cemaran logam } \\
\hline a. Timbal $(\mathrm{Pb})(\mathrm{mg} / \mathrm{kg})$ & 1,21 & 1,05 \\
\hline b. Tembaga $(\mathrm{Cu})(\mathrm{mg} / \mathrm{kg})$ & $<0,0067$ & $<0,0067$ \\
\hline c. Seng $(\mathrm{Zn})(\mathrm{mg} / \mathrm{kg})$ & 4,62 & 4,75 \\
\hline d. Arsen (As) (mg/kg) & 0,03 & $<0,0008$ \\
\hline \multicolumn{3}{|l|}{ Cemaran mikroba } \\
\hline $\begin{array}{l}\text { a. Angka Lempeng Total } \\
\text { (ALT) (koloni/g) }\end{array}$ & $18,0 \times 10^{2}$ & $8,4 \times 10^{2}$ \\
\hline b. Coliform (APM/g) & 28 & $<3$ \\
\hline
\end{tabular}

Pada Tabel 3 juga terlihat bahwa sekalipun jumlah cemaran mikroba telah berhasil diturunkan dengan menggunakan proses pasteurisasi namun kualitas susu tetap terjaga. Hal ini dapat dilihat pada hasil pengukuran terhadap berat jenis, jumlah kandungan lemak dan jumlah kandungan protein yang relatif tidak berubah setelah susu mengalami proses pasteurisasi.

\section{KESIMPULAN}

Pada penelitian ini telah dibangun sistem pengendali proses pasteurisasi susu dengan menggunakan pengendali PID dan pengendali Fuzzy. Sistem pasteurisasi susu mengikuti standar pasteurisasi Low Temperature Long Time (LTLT) dengan target suhu pemanasan sebesar $64{ }^{\circ} \mathrm{C}$ selama rentang waktu 30 menit. Berdasarkan hasil pengujian diperoleh kesimpulan bahwa sistem pengendali PID dengan nilai $K_{p}=31,8 ; K_{I}=117,8 ; K_{D}=4,3$ memberikan respon lebih cepat daripada sistem pengendali Fuzzy berdasarkan pengukuran indikator waktu tunda, waktu naik, waktu puncak dan waktu penetapan. Sebaliknya sistem pengendali Fuzzy menghasilkan nilai MSE lebih kecil daripada sistem pengendali PID yang menunjukkan bahwa sistem pengendali Fuzzy memiliki fluktuasi kesalahan lebih kecil daripada sistem pengendali PID dalam proses pasteurisasi susu. Akan tetapi, karena nilai MSE kedua pengendali berada di bawah 1\%, maka diperoleh kesimpulan bahwa capaian suhu susu kedua pengendali dapat memenuhi rentang standar pasteurisasi susu. Hasil pengujian laboratorium menunjukkan bahwa proses pasteurisasi telah berhasil menurunkan jumlah mikroba sesuai SNI 013951-1995 tentang susu pasteurisasi, pada saat yang sama proses ini juga berhasil mempertahankan kualitas susu.

\section{UCAPAN TERIMA KASIH}

Penulis mengucapkan terima kasih kepada Kementerian Riset, Teknologi dan Pendidikan Tinggi Republik Indonesia, atas pendanaan penelitian pengabdian masyarakat ini melalui Hibah Program Kemitraan Masyarakat Tahun Anggaran 2018 dari DRPM Ditjen Penguatan Risbang.

\section{DAFTAR PUSTAKA}

ALAMIREW, T., BALAJI, V. dan GABBEYE, N., 2017. Comparison of PID controller with model predictive control for milk pasteurization process. Bulletin of Electrical Engineering and Informatics, 6(1), p. 24-35.

ANANG, HADISUPADMO, S, dan LEKSONO, E., 2016. Model predictive control design and performance analysis of a pasteurization process plant. Prosiding International Conference on Instrumentation, Control and Automation (ICA), Bandung, Indonesia.

ATMEL, 2002. 8-bit AVR Microcontroller with 16K Bytes In-System Programmable Flash. San Jose, California, USA: ATMEL.

ICHSAN, M.H.H., SETIAWAN, E. dan HAMIDI, M.A., 2016. Implementasi logika fuzzi pada sistem berbasis field programmable gate array (FPGA). Jurnal Teknologi Informasi dan Ilmu Komputer, 3(1), p. 75-82. 
MAULANA, Y. Z., HADISUPADMO, S, dan LEKSONO, E., 2016. Performance analysis of PID controller, Fuzzy and ANFIS in pasteurization process. Prosiding International Conference on Instrumentation, Control and Automation (ICA), Bandung, Indonesia.

MAXIM INTEGRATED PRODUCTS, 2015. Programmable resolution 1-wire digital thermometer. San Jose, California, USA: Maxim Integrated Products, Inc.

OGATA, K., 2010. Modern Control Engineering. $5^{\text {th }}$ ed. Upper Saddle River, NJ, USA: Prentice Hall.

POUR, F.K., PUIC, V., dan MARTINEZ, C.O., 2017. Comparative assessment of LPV-based predictive control strategies for a pasteurization plant. Prosiding International Conference on Control, Decision and Information Technologies (CoDIT), Barcelona, Spain.

RESNAWATI, H., 2008. Kualitas susu pada berbagai pengolahan dan penyimpanan. Prosiding seminar nasional prospek industri sapi perah menuju perdagangan bebas - 2020, Jakarta, [e-proceeding]. Tersedia di < http://perpustakaanpuslitbangnak.blogspot.com/2014/12/prosid ing-prospek-industri-sapi-perah.html > [diakses pada 30 Juli 2018]

SALEH, E., 2004. Teknologi pengolahan susu dan hasil ikutan ternak. Medan: USU Digital Library, [e-journal]. Tersedia melalui: Perpustakaan Universitas Sumatra Utara < http://library.usu.ac.id/download/fp/ternakeniza.pdf> [Diakses 30 Juli 2018]

SETYAWAN, G.E., SETIAWAN, E. dan KURNIAWAN, W., 2015. Sistem kendali ketinggian quadcopter menggunakan PID. Jurnal Teknologi Informasi dan Ilmu Komputer, 2(2), p. 125-131.

SRISUMA, C., SANTALUNA, S., THOSDEEKORAPHAT, T., dan THONGSOPA, C., 2017. The analysis and design of milk pasteurization system by using radio frequency electric fields. Prosiding Asia-Pacific International Symposium on Electromagnetic Compatibility, Seoul, Korea.

SUWITO, W., 2010. Bakteri yang sering mencemari susu: deteksi, patogenesis, epidemiologi, dan cara pengendaliannya. Jurnal Litbang Pertanian, 29(3), p. 96-100. 